\title{
DIAGNOSTIC METHODOLOGY FOR THE ENERGY EFFICIENCY ESTIMATION IN SMALL METAL CASTING INDUSTRIES
}

\author{
Sonia Gómez Moreno, Yuri Ulianov López Castrillón y Carlos Eduardo Roncancio Uribe \\ Department of Energetic and Mechanic \\ Universidad Autónoma de Occidente \\ Km.2 Vía a Jamundí, Cali (Colombia) \\ Phone: (572) 318 8000, Fax: (572) 5553911 \\ e-mail: sgomez@cuao.edu.co,yulianov@cuao.edu.co,ceruribe@cuao.edu.co
}

\begin{abstract}
This study will develop a methodology to measure and find the energy efficiency in arc furnaces, crucible furnaces and cupola furnaces. Those are the only ones used in the small metal casting industries in Cali.

The methodology initiates with the elaboration of a survey and contacting a sample OF local companies, then, continues with technical visits, measurements, analysis and results and finally, we obtain conclusions and give some specific recommendations to the companies
\end{abstract}

As a result, the first documented characterization were done, where is shown: size of the industry, energetic resource used, level of technification (modernization), fused metal, smelting method and kind of furnace, it is also presented the validation methodology and the identification of critical points where they can obtain big energy savings.

\section{Key words}

PYMES, Energetic Efficiency, Energetic Audit, Diagnostic.

\section{Introduction}

Small industries must face other industries competence and the beginning of new commerce rules and treaties such as NAFTA and FTA.

One of the main factors that affect in a negative way the cost of productivity is the inefficient use of energy; therefore, application of these concepts must begin in businessmen helped by the university. In this way, this project started with previous studies such as "Energetic efficiency and the environment, Marketing research, Small, Medium and Large Industries in the city of Cali”"1. This research shows the level of knowledge that companies/businessmen have about energy efficiency

\footnotetext{
1 Professors of Thermal Sciences and Fluids Mechanic Area. Energetic efficiency and the environment, Marketing research, Small, Medium and Great Industries in the city of Cali. Mechanical Engineering, Universidad Autónoma de Occidente. January 2001. Cali. Colombia
}

and the necessity of minimize production costs through energy savings. It is also considering:

- $100 \%$ of industries wish to minimize costs on energy consumption.

- $60 \%$ have not realize technical and serious studies to minimize energy consumption.

- $44 \%$ of those industries don’t know about audit energetic.

- Most of industries work their equipments without considering their best performance (appropriate fuel, environmental impact, optimal work conditions and also whether if is possible to optimize melting process to reduce costs or simply to know what's the relation between energy consume and production.

To satisfy necessities of this Metal Casting Industry, the research is looking for a specific and useful methodology giving as a result the energy efficiency in all furnaces.

The project contribution is to give Energy Efficiency Indexes to Small Metal Casting Industries (in Spanish known as PYMES), and also to give them the identification of points with high Energy consume. A characterization of this sector that is also given here would allow businessmen a real view of their process and a good way to improve productivity.

Some case studies of "energy uses" and "potential areas" for savings within foundry operations are also presented in this research.

\section{Creating the methodology.}

As a reference in this project it is consider, a recent National Law (697 de 2001), which in its 1st article declare the Rational and Efficient Use of Energy (URE) as a matter of public and social interest, and a matter of a national convenience [1]. It is also consider that the Small Metal Casting Industry in Cali - Colombia, have obsoletes equipments built in a handmade way; in addition, some industries do not have equipments to measure and control process and the ones who have some, they are low level of modernization. 
Furnaces in melting process work with Used Oil (Burned.), causing high level of contamination in addition to their thermal efficiency loss. [2]

\section{A. Methodology developed}

To the energy diagnosis developed, a Mexican proposal was considered. It is defined like "First level diagnosis", by the Electricity Federal Commission (Comisión Federal de Electricidad de México). Another Energetic diagnostic developed by Sugar Cain Research Centre (CENICAÑA), realized in Sugar Cain industries in this region were considered.

All this proposals give a real reference frame to the methodology created.

1) Survey

2) Contacting Industries: Contact with the company: A data base of metallurgical sector PYMES was consulted, where the name of businessmen. Contact were made by electronic mail, fax and/or telephone, informing him objectives and the diagnosis advantages to make a energetic analysis inside the Industry. After the calling some appointments to apply the survey were done.

3) Energetic Audit: It is made a technical visit to the company, to inspect visually state of equipments and installation. It is also watched the melting process while the survey is realized to obtain consumption data and production and energetic costs.

A Chilean researcher, Gabriel Olguín [2], says that this type of diagnosis is called "energetic prediagnosis”, where some general industry data are obtain through a survey and also the energetic resources in the industry.

In this stage also an environmental observation was made; since a good labor atmosphere gives the workers a better space that allows them to make a more efficient work.

4) Measurement of energy parameters: CANDURA POWER y TESTO 350 were used to take power and thermal measures.

5) Diagnosis, results delivery and recommendations: Data of the measurement process are analyzed, evaluates the energy consumption, indexes of energetic efficiency are obtained and improvement strategies are identified..

\section{B. Survey}

The survey, try to get the information listed below:
1) Organizational Information: Activity of the company and area of performance, number of employees, labor day.

2) Technical Information: Voltage level, Power and electrical equipment (transformers, electrical motors, lighting and arc furnaces), Electric Company, Energy consumptions of the last year. Calorific Powers. Type of smelting processes. Types of Furnaces. Products and Production

First of all, a survey was created but it needed some adjustments once the research team visit the industry. That survey was improved and make it more specific to the Metal Casting Industry; as well as some marketing and statistics survey models were applied to optimize it.

\section{Energetic parameters.}

The energy balance depends on the kind of meeting process. It could be continuous having a production flux measured on $\mathrm{kg} / \mathrm{h}$ o $\mathrm{Ton} / \mathrm{h}$, or by pockets, where production is measured by the load fused in each pocket, and it is in $\mathrm{kg}$ or tons.

Temperature in continuous process is kept constant and the temperature of the load varies between the point the load is get into the furnace and the point where the load is extracted from the furnace. In the non continuous process of smelting, the load temperature varies along the process it is logical that during the change of phase single latent heat acts of fusion and sensible non heat.

In the non continuous process of smelting, the furnace temperature decreases when the load is being put into the furnace since the coating yields its heat to him; then the combustion energy is again dedicated to warm up the coating and to warm up the load until the temperature of fusion.

The total value of energy efficiency on furnaces can be calculated as shown [3]:

$\eta_{T}=\eta_{C O M B} \cdot \eta_{I N T}$

Where:

$\eta_{T}: \quad$ Total efficiency

$\eta_{C O M}$ : $\quad$ Combustion efficiency

$\eta_{\text {INT }}$ : $\quad$ Furnace Internal efficiency

So:

$$
\eta_{\text {CомвUSтION }}=\frac{\text { Absorbed.heat }}{\text { Supplied.heat }}
$$

Then: 


$$
\eta_{C O M B}=1-\frac{\dot{Q}_{g}}{\dot{Q}}
$$

$\dot{Q}_{g}$ : $\quad$ flow of lost heat by the smoke

$\dot{Q}$ : flow of Combustion heat

In this expression other sources of heat have been eliminated, like: sensible heat of preheated air, the sensible heat of the preheated fuel and the heat of exothermic reactions. These sources do not appear at the furnaces and processes that were evaluated in this study.

Then:

$$
\dot{Q}=\dot{B}_{c} \cdot P C I_{h}
$$

Where:

$\dot{B}_{c}$ : $\quad$ Fuel volumetric $(\mathrm{kg} / \mathrm{h})$ or $\left(\mathrm{Nm}^{3} / \mathrm{h}\right)$

PCIh: Low Calorific Value of humid fuel $(\mathrm{kJ} / \mathrm{kg})$ or $\left(\mathrm{kJ} / \mathrm{Nm}^{3}\right)$

$$
\dot{Q}_{g}=\dot{B}_{c} \cdot\left[W_{\text {hum }}+(\alpha-1) \cdot W_{\text {air }}\right] \cdot C_{\text {hum }} \cdot T_{\text {hum }} \text { salida }
$$

$W_{\text {hum }}$ : Weight of produced humid theoretical smoke in the stoichiometric combustion of the fuel in $(\mathrm{kg} / \mathrm{kg})$ or $\left(\mathrm{kg} / \mathrm{Nm}^{3}\right)$

$\alpha$ : $\quad$ Coefficient of excess of air

$W_{\text {air }}$ : Weight of the theoretical air for the stoichiometric combustion (kg/Unit of fuel). When the combustion air is to room temperature (they assume $25^{\circ} \mathrm{C}$ ) this I finish is normally despicable

$C_{\text {hum }}$ : Heat capacity specifies average of the smoke $\left(\mathrm{kJ} / \mathrm{kg}{ }^{\circ} \mathrm{C}\right)$

$T_{\text {hum output }}$ : Temperature of the smoke when coming out of the furnace

And

$$
\eta_{I N T}=\frac{\dot{Q}_{F}}{\dot{Q}_{F}+\dot{Q}_{e s c}+\dot{Q}_{e n d}+\dot{Q}_{c o n d}+\dot{Q}_{r a d}+\dot{Q}_{r e f r}+\dot{Q}_{r e v}+\dot{Q}_{\text {ind }}}
$$

Where:

$\dot{Q}_{F}$ Useful heat to fuse the load $(\mathrm{kJ} / \mathrm{h})$

$\dot{Q}_{\text {esc }}$ : Lost heat by dreg

$\dot{Q}_{\text {end }}$ : Heat by endothermic reactions $(\mathrm{kJ} / \mathrm{h})$

$\dot{Q}_{\text {cond }}$ : Lost heat by conduction through the walls of the furnace $(\mathrm{kJ} / \mathrm{h})$

$\dot{Q}_{\text {rad }}$ : Lost heat by radiation through doors, openings, etc. $(\mathrm{kJ} / \mathrm{h})$

$\dot{Q}_{\text {refr }}$ : Lost heat by the refrigeration water $(\mathrm{kJ} / \mathrm{h})$
$\dot{Q}_{\text {rev }}$ : Lost heat by accumulation in the coating $(\mathrm{kJ} / \mathrm{h})$

$\dot{Q}_{\text {ind }}$ : Lost heat by undefinided. Some authors take $10 \%$ from the sum of the lost heat by un burned gaseous, lost heat by unburned solid, lost heat by conduction, lost heat by the refrigeration water and the lost heat in the coating $(\mathrm{kJ} / \mathrm{h})$

\section{Variables Measurement:}

1, Temperature: In order to register diverse temperatures a KANE, Optical Pyrometer (Range: $600{ }^{\circ} \mathrm{C}$ to $1800{ }^{\circ} \mathrm{C}$ ), was used. Also a TESTO equipment with temperature soundings (Range $-200{ }^{\circ} \mathrm{C}$ to $1370{ }^{\circ} \mathrm{C}$ ), were used to register the air combustion temperature, and the load temperature before introducing it inside the furnace.

2. Air Flux. An anemometer to measure the air was used at the Combustion Fan entrance with a TESTO Vane anemometer and measurements data with data logger Testo 454.

3. Combustion Gases: It was tried to measure combustion gases with Analysis box flue gas parameters such as $\mathrm{O} 2$, $\mathrm{CO}, \mathrm{NO}, \mathrm{NO} 2, \mathrm{NOx}, \mathrm{SO} 2, \mathrm{H} 2 \mathrm{~S}$ differential pressure and velocity measurement with Pitot tube.

Multiple difficulties were found to measure gas parameters, because it is required to channels the flue gases through a chimney. It is because crucible furnaces are opened to the atmosphere and they don't have a channel for gases.

The research team realize an experiment to measure gases putting a tube to channel them, placing a chimney under the furnace cover. Nevertheless, it was not successful because the flame still remains by the mouth of the tube (forming a torch), disabling the measurement because sounding held in contact with the flame and not with gases. In addition to that, the heat radiation to the environs is high, making uncomfortable and uncertain the measurement to the person who makes its. In the cupola furnaces, the same phenomenon appears.

4. Power: For electric energy measurements was used a CANDURA POWER equipment to obtain voltage, current, disturbances (Harmonics), and t observe most of the power quality typical troubles, as well as the consumed power.

The equipment is setup according to Voltage level and under IEEE specifications RECOMMENDATIONS (IEEE 519 and others).

Data helps are compared with energy bill values. 
Waveforms analysis of phase currents on Arc Furnace:

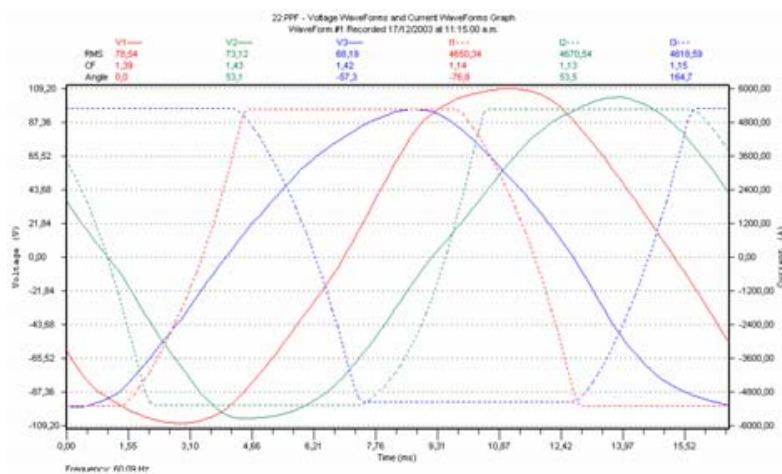

Figure 1. Voltage level

\section{E. Industries Characterization - Case study}

To keep in privacy industries values and avoid legal troubles, names were changed in the results.

\begin{tabular}{|c|c|c|c|}
\hline PLANT & $\begin{array}{c}\text { COLOMBIAN } \\
\text { CAMERA } \\
\text { COMMERCE } \\
\text { CLASSIFICATION } \\
\end{array}$ & $\begin{array}{l}\text { FUSED } \\
\text { METAL }\end{array}$ & $\begin{array}{c}\text { USED } \\
\text { FURNACE }\end{array}$ \\
\hline A & Medium & Bronze & Crucible \\
\hline $\mathrm{B}$ & Medium & Iron & Cupola \\
\hline $\mathrm{C}$ & Small & Iron & Cupola \\
\hline $\mathrm{D}$ & Small & Plumb & Cupola \\
\hline $\mathrm{E}$ & Small & $\begin{array}{c}\text { steel } \\
\text { fused iron } \\
\text { aluminium } \\
\text { bronze }\end{array}$ & $\begin{array}{c}\text { Arc } \\
\text { Cupola } \\
\text { Fixed Crucible } \\
\text { AND } \\
\text { Tilted Crucible }\end{array}$ \\
\hline $\mathrm{F}$ & Small & $\begin{array}{l}\text { aluminium } \\
\text { bronze }\end{array}$ & $\begin{array}{c}\text { Fixed } \\
\text { Crucible }\end{array}$ \\
\hline G & Micro company & $\begin{array}{l}\text { fused iron } \\
\text { aluminium } \\
\text { bronze }\end{array}$ & $\begin{array}{c}\text { Cupola } \\
\text { Fixed Crucible }\end{array}$ \\
\hline
\end{tabular}

\begin{tabular}{|c||c|c||c||}
\hline \hline PLANT & $\begin{array}{c}\text { SMELTING } \\
\text { METHOD }\end{array}$ & FUEL & $\begin{array}{c}\text { MODERNIZATION } \\
\text { LEVEL } \\
\text { Equipment } \\
\text { of Smelting }\end{array}$ \\
\hline \hline A & $\begin{array}{c}\text { Continuous } \\
\text { casting vertical } \\
\text { Moulding }\end{array}$ & Burned oil & Low \\
\hline \hline B & Moulding & Coke & low \\
\hline \hline C & Centrifugado & Coke & Medium \\
\hline \hline D & $\begin{array}{c}\text { Continuous } \\
\text { casting vertical } \\
\text { Moulding }\end{array}$ & Coke & Medium \\
\hline \hline E & Moulding & $\begin{array}{c}\text { Electrical } \\
\text { Energy } \\
\text { Coke }\end{array}$ & Low \\
\hline \hline $\mathrm{F}$ & Moulding & Burned oil & \\
\hline \hline $\mathrm{G}$ & Moulding & $\begin{array}{c}\text { Coked oil } \\
\text { Burned oil }\end{array}$ & Low \\
\hline
\end{tabular}

A similar characterization was made in North American companies of smelting [ 4 ].

\section{F. Energetic Indexes}

Energetic indexes can be defined once the energy consumption (included all energy resources electric energy and fuels), has been clearly identified in each industry.

It is consider that an important aspect to raise the service productive sector awareness and motivate the sector to implement energy efficiency programs is the determination of consumption indexes by sectors (in this case Metallurgical), both globally and by processes. This projects intent to determine these indexes.

Indexes relate energy consumption per finished product unit, to identify amount of energy consumed in some process. In this case, product can be kilos of bronze bars or tons of iron.

Next table presents measurements and some calculated parameters needed to diagnosis and to identify energetic indexes: 
TABLE 2. DIAGNOSIS DATA BASE

\begin{tabular}{|c|c|c|c|c|c|c|c|c|c|c|c|}
\hline Industry & Metal & Furnace & Fuel & \multicolumn{2}{|c|}{ Fuel flux } & \multicolumn{2}{|c|}{ Heat power of Fuel } & \multicolumn{2}{|c|}{$\begin{array}{c}\text { Energy } \\
\text { Consumption } \\
(\mathbf{k W})\end{array}$} & $\begin{array}{c}\text { Furnace } \\
\text { production } \\
(\mathrm{kg})\end{array}$ & $\begin{array}{c}\text { Energetic } \\
\text { Index } \\
\mathbf{k W} / \mathbf{k g}\end{array}$ \\
\hline 1 & Bronze & Crucible & $\begin{array}{c}\text { Oil- } \\
\text { burned }\end{array}$ & 5 & $\mathrm{Gl} / \mathrm{h}$ & 138000 & $\mathrm{Btu} / \mathrm{Gl}$ & 202 & $\mathrm{~kW}$ & 200 & 1 \\
\hline \multirow{4}{*}{2} & Steel & Cupola & Coque & 1150 & $\mathrm{~kg} / \mathrm{h}$ & 24200 & $\mathrm{Btu} / \mathrm{kg}$ & 8157 & $\mathrm{~kW}$ & 20 & 408 \\
\hline & Steel & Arco & Electricity & & & & & 665 & $\mathrm{~kW}$ & 700 & 1 \\
\hline & Aluminum & Crucible & $\begin{array}{c}\text { Oil- } \\
\text { burned }\end{array}$ & 10 & $\mathrm{Gl} / \mathrm{h}$ & 138000 & Btu/Gl & 404 & $\mathrm{~kW}$ & 20 & 20 \\
\hline & Bronze & Crucible & $\begin{array}{c}\text { Oil- } \\
\text { burned }\end{array}$ & 15 & $\mathrm{Gl} / \mathrm{h}$ & 138000 & Btu/Gl & 607 & $\mathrm{~kW}$ & 75 & 8 \\
\hline 3 & Steel & Cupola & Coque & 480 & $\mathrm{~kg} / \mathrm{h}$ & 24200 & $\mathrm{Btu} / \mathrm{kg}$ & 3404 & $\mathrm{~kW}$ & 900 & 4 \\
\hline 4 & Plumb & Cupola & Coque & 250 & $\mathrm{~kg} / \mathrm{h}$ & 24200 & $\mathrm{Btu} / \mathrm{kg}$ & 1773 & $\mathrm{~kW}$ & 3500 & 1 \\
\hline \multirow{4}{*}{5} & Steel & Cupola & Coque & 125 & $\mathrm{~kg} / \mathrm{h}$ & 24200 & $\mathrm{Btu} / \mathrm{kg}$ & 887 & $\mathrm{~kW}$ & 525 & 2 \\
\hline & Steel & Arco & Electricity & & & & & 130 & $\mathrm{~kW}$ & 120 & 1 \\
\hline & Aluminum & Crucible & $\begin{array}{c}\text { Oil- } \\
\text { burned }\end{array}$ & 0,5 & $\mathrm{Gl} / \mathrm{h}$ & 138000 & Btu/Gl & 20 & $\mathrm{~kW}$ & 30 & 1 \\
\hline & Copper & Crucible & $\begin{array}{c}\text { Oil- } \\
\text { burned }\end{array}$ & 13,8 & $\mathrm{Gl} / \mathrm{h}$ & 138000 & Btu/Gl & 556 & $\mathrm{~kW}$ & 100 & 6 \\
\hline \multirow{2}{*}{6} & Aluminum & Crucible & $\begin{array}{c}\text { Oil- } \\
\text { burned }\end{array}$ & 8,3 & $\mathrm{Gl} / \mathrm{h}$ & 138000 & Btu/Gl & 336 & $\mathrm{~kW}$ & 40 & 8 \\
\hline & Copper & Crucible & $\begin{array}{c}\text { Oil- } \\
\text { burned }\end{array}$ & 11 & $\mathrm{Gl} / \mathrm{h}$ & 138000 & Btu/Gl & 445 & $\mathrm{~kW}$ & 62 & 7 \\
\hline \multirow{3}{*}{7} & Steel & Cupola & Coque & 64 & $\mathrm{~kg} / \mathrm{h}$ & 24200 & Btu/kg & 454 & $\mathrm{~kW}$ & 150 & 3 \\
\hline & Aluminum & Crucible & $\begin{array}{c}\text { Oil- } \\
\text { burned }\end{array}$ & 12 & $\mathrm{Gl} / \mathrm{h}$ & 138000 & Btu/Gl & 485 & $\mathrm{~kW}$ & 25 & 19 \\
\hline & Bronze & Crucible & $\begin{array}{c}\text { Oil- } \\
\text { burned }\end{array}$ & 5 & $\mathrm{Gl} / \mathrm{h}$ & 138000 & Btu/Gl & 202 & $\mathrm{~kW}$ & 90 & 2 \\
\hline
\end{tabular}


For example in the Sugar sector some indexes were identified taking account into annual consumption of energy and finished product unit which would be expressed like Gigajoules of energy consumed by each ton of product, GJ/Ton. [5] [6]:

$$
I=\frac{G J}{T o n}
$$

In our case, the indexes, were found with energetic consumption data and production, fundamentally per month, although could be used a different period of time.

Indexes will serve as statistical comparison to all industries to know the Energetic consumption in similar periods of production. In Mexico, the National Commission for Energy Saving - CONAE, sugest all industries a comparison and it is named INTERNAL BENCHMARKING. ${ }^{2}$

INDUSTRY A: Crucible Furnace. Process: Continuous casting. Combustible oil-burned (used) - Product: Bronze.

This process lasts 1 hour in average. It uses 5 gallons of oil-burned to produce 200 Kilograms of product. The Index is:

$$
\begin{aligned}
& \text { FLOW.FUEL }=\frac{5 \mathrm{gal}}{\mathrm{h}} * 138000 \frac{\mathrm{BTU}}{\mathrm{gal}}= \\
& 690.000 \frac{\mathrm{BTU}}{\mathrm{h}} * \frac{1 \mathrm{KW}}{3412 \mathrm{BTU} / \mathrm{h}}=202.227 \mathrm{KW} \\
& I=\frac{\text { energy }}{\text { product }}=\frac{1.011 \mathrm{KW}}{\mathrm{Kg}}
\end{aligned}
$$

INDUSTRY B: Furnace: Crucible-Retaining (continuous process). Combustible: oil-burned (used). Product: Aluminum. Process: It lasts 1 hour in average and used 10 gallons of oil-burned to produce 20 Kilograms of aluminum. The Index calculates thus:

(9)

$$
\begin{aligned}
& \text { FLOW.FUEL }=\frac{10 \mathrm{gal}}{h} * 138000 \frac{\mathrm{BTU}}{\mathrm{gal}}= \\
& =1^{\prime} 380.000 \frac{\mathrm{BTU}}{\mathrm{h}} * \frac{1 \mathrm{KW}}{3412 \mathrm{BTU} / \mathrm{h}}=404.45 \mathrm{KW} \\
& I=\frac{\text { energy }}{\text { product }}=\frac{404.45 \mathrm{KW}}{20 \mathrm{Kg}}=20.22 \frac{\mathrm{KW}}{\mathrm{Kg}}
\end{aligned}
$$

INDUSTRY C: $150 \mathrm{~kg}$ of Iron (Raw material), are used. Fuel: Coque 80 kg.Process: 10 minutes. The index is then:

\footnotetext{
${ }^{2}$ http://www.conae.gob.mx/wb/distribuidor.jsp?seccion=2788
}

$$
\begin{gathered}
\dot{B}=\frac{80 \mathrm{Kg}}{10 \mathrm{~min}}=\frac{480 \mathrm{Kg}}{1 \mathrm{~h}} \\
\dot{m}_{\mathrm{Fe}}=\frac{150 \mathrm{Kg}}{10 \mathrm{~min}}=\frac{900 \mathrm{Kg}}{1 \mathrm{~h}}
\end{gathered}
$$

$I=\frac{\text { power }}{\text { product }}$

$$
\begin{aligned}
& =\frac{480 \mathrm{Kg} / \mathrm{h} * 24200 \mathrm{BTU} / \mathrm{Kg} * 1 \mathrm{KW} / 3412 \mathrm{BTU} / \mathrm{h}}{900 \mathrm{Kg}} \\
& =\frac{3404.45 \mathrm{KW}}{900 \mathrm{Kg}}=3.78 \frac{\mathrm{KW}}{\mathrm{Kg}}
\end{aligned}
$$

Next table shows some results obtained, in aluminium case:

\section{TABLE 3. ALUMINIUM MELTING IN CRUCIBLE} FURNACES

\begin{tabular}{|c|c|c|c|}
\hline INDUSTRY & $\begin{array}{c}\text { Energy } \\
\text { consumed } \\
\mathbf{k W}\end{array}$ & $\begin{array}{c}\text { Furnace } \\
\text { production } \\
\mathbf{( k g )}\end{array}$ & $\begin{array}{c}\text { Index } \\
\mathbf{k W} / \mathbf{k g}\end{array}$ \\
\hline 2 & 404,5 & 20 & 20 \\
\hline 5 & 20,2 & 30 & 1 \\
\hline 6 & 335,7 & 40 & 8 \\
\hline 7 & 485,3 & 25 & 19 \\
\hline
\end{tabular}

The following figure shows a comparison of the energy efficiency for the aluminium production at metal casting industries.

As seen on it, the company $\mathrm{E}$ has the best index, but statistically this result must be reviewed because it is far away from the average. Also great consumptions of energy with low production in companies B and G are observed.

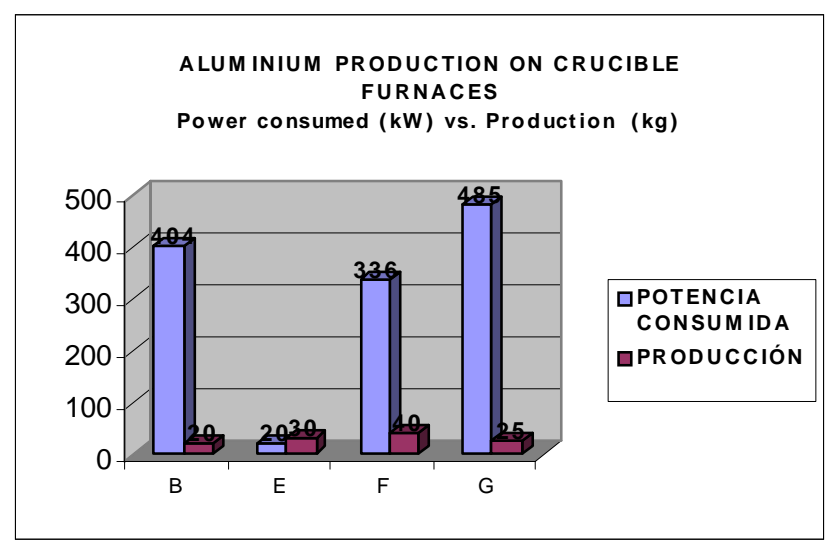

Figure 2. Comparison of energy consumption against production on crucible furnaces. 


\section{G. Difficulties to face with}

There are some difficulties found during the project development. High contamination levels, deficient use of moulding sands, and mainly a little interest on businessmen, to investment in technical reforms to improve the efficiency.

Raw material: There was a crisis in metal casting sector to find the raw material some years ago. In 2003, the scrap iron began to be sold easily and highly to neighboring countries like Ecuador, increasing costs in $21 \%$ for bronze and $150 \%$ for aluminium, this way they used another materials decreasing efficiency and increasing product costs.

Another difficulty was to measure combustion gases on crucible and cupola furnaces, because the first ones do not have a way to conduct gases without flame and cupola furnaces flames avoid the gas measurement. The measurement process must be ON gases, it can not be make it on flame presence. Then, values of combustion products must calculate in theoretical form (stoichiometric equation of combustion).

There is not a software that could be used in those industries. Unless, to realize diagnosis more than one software be used.

Some other difficulties are shown on Table 4. as a weaknesses.

\section{CONCLUSIONS}

In spite of the difficulties found like troubles with gases measurements, the initial rejection of the businessmen (75\% did not show greater interest), and a poor industry answer to this project from more than 20 industries; the project allowed to develop the first methodology to determine the energetic consumption level in a metallurgical company in Cali - Colombia and a estimative of some industry indexes for small and medium industries with the raised conditions.

It is clear that with energy consumption and energetic indexes all these industries could create a energy saving program, compare indexes every single month or year depending the measurements capabilities (internally), to develop strategies of improvement in costs reduction.

Another parallel result is a first characterization of these companies.

The indexes must comparing between the same company at different times or between similar processes with equal conditions and characteristics, also the index can be compared modifying a variable like the type of fuel.

The Methodology developed in these industries shows a very low automation level on smelting equipment and a high environmental impact reducing workers efficiency, also creating great times of smelting, greater energetic consumption and reducing product quality.

Table 4. Industry weaknesses and suggestions

\begin{tabular}{|c|c|c|}
\hline $\mathbf{N}^{\circ}$ & $\begin{array}{r}\text { OBSERVED } \\
\text { WEAKNESSES }\end{array}$ & RECOMMENDATIONS \\
\hline 1 & $\begin{array}{l}\text { Accelerated } \\
\text { deterioration of } \\
\text { electrical equipment, } \\
\text { by abuse, incorrect } \\
\text { location and/or null } \\
\text { maintenance. }\end{array}$ & $\begin{array}{l}\text { Conservation of motors } \\
\text { plates of characteristics and } \\
\text { preventive maintenance of } \\
\text { them. }\end{array}$ \\
\hline 2 & $\begin{array}{l}\text { Little or null culture } \\
\text { in Rational Use of } \\
\text { Energy as far as the } \\
\text { Efficient equipment } \\
\text { operation. }\end{array}$ & $\begin{array}{l}\text { Qualification in rational use } \\
\text { of energy (URE) through } \\
\text { courses. }\end{array}$ \\
\hline 3 & $\begin{array}{l}\text { Low lighting levels in } \\
\text { zones of moulding } \\
\text { and smelting, } \\
\text { deteriorate lamps in } \\
\text { mechanized zones }\end{array}$ & $\begin{array}{l}\text { To take advantage of the } \\
\text { sunlight to illuminate during } \\
\text { the day and lighting system } \\
\text { with energy saving lamps. }\end{array}$ \\
\hline 4 & $\begin{array}{l}\text { The combustion } \\
\text { gases, circulating } \\
\text { around the facilities } \\
\text { in spite of having } \\
\text { extractors or } \\
\text { chimneys . }\end{array}$ & $\begin{array}{l}\text { Redesign gases extraction } \\
\text { system. }\end{array}$ \\
\hline 5 & $\begin{array}{l}\text { Too many workers do } \\
\text { not use industrial } \\
\text { protective equipment. } \\
\text { Even engineers. }\end{array}$ & $\begin{array}{l}\text { Use of masks and other } \\
\text { protective equipment when } \\
\text { operating the furnaces. }\end{array}$ \\
\hline 6 & $\begin{array}{l}\text { Furnaces of smelting } \\
\text { in bad conditions } \\
\text { repaired and operated } \\
\text { in a home made form. }\end{array}$ & $\begin{array}{l}\text { Technical repair of the } \\
\text { equipment with the norms } \\
\text { and suitable characteristics. } \\
\text { Ask for technical help at } \\
\text { universities or technical } \\
\text { schools }\end{array}$ \\
\hline 7 & $\begin{array}{l}\text { Furnaces do not have } \\
\text { installed equipment } \\
\text { to measure } \\
\text { temperature. }\end{array}$ & $\begin{array}{l}\text { Installation of measurement } \\
\text { equipment.. }\end{array}$ \\
\hline 8 & $\begin{array}{l}\text { The use of Used fuel } \\
\text { without knowing its } \\
\text { origin and } \\
\text { characterization, } \\
\text { which producing } \\
\text { health troubles on } \\
\text { workers. }\end{array}$ & $\begin{array}{l}\text { To change the oil-fuel used } \\
\text { by coke or natural gas, after } \\
\text { a technical study. } \\
\text { Or } \\
\text { Ask the suppliers for fuel } \\
\text { characterization. }\end{array}$ \\
\hline
\end{tabular}


For future exercises, it is considered very important to show the businessmen a simple block diagram to make him understand in a simple way how this kind of job will be. [ 7 ].

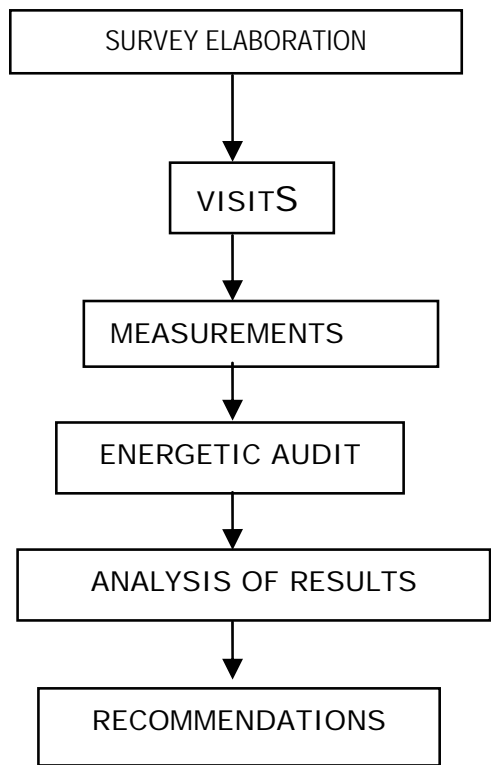

\section{Acknowledgements}

The authors want to thankful PRODISTEC, CONALBRONCES, FUNDICIONES TORRES, METALEX, IMEVALLE, TUBERÍAS METALICAS DE COLOMBIA and University support through Research Office ( In spanish Vicerectoría de Investigaciones).

\section{References}

\section{[1] CONGRESO DE LA REPUBLICA DE} COLOMBIA. Ley 697 de 2001. Ley URE. Bogota Colombia. (2001).

[2] OLGUIN PARADA GABRIEL M. Uso eficiente de la Energía Eléctrica; Una estrategia de desarrollo sustentable. Universidad de Santiago de Chile, Departamento de Ingeniería Eléctrica, Tesis de titulación-Ingeniero Civil en Electricidad. Chile (1994).

[3] MOLINA IGARTÚA, LUIS ALFONSO; MOLINA IGARTÚA, GONZALO. Manual De Eficiencia Energética Térmica en la Industria. Ente Vasco de la Energía, Bilbao, Diciembre (1993).

[4] JENDRUKO, RICHARD. BORDELON, GORDON. Energy Engineering, Opportunities for foundry energy conservation based on selected case studies. Atlanta. USA.( 2003 ).

[5] CONSEJO EMPRESARIAL COLOMBIANO PARA EL DESARROLLO SOSTENIBLE. Indicadores de sostenibilidad. Bogota (2002 ). Asocaña. 2002
[6] GUTIÉRREZ CORREA, ALEXANDRA MARÍA ahorro de la energía eléctrica en instalaciones industriales. diplomado corporación universitaria autónoma de occidente. módulo1 uso eficiente de la energía. DIAGNÓSTICO Y GESTIÓN. Santiago de Cali. Colombia.( 2001).

[7] ANDI, Empresas públicas de Medellín y Universidad Pontificia Bolivariana-GET-. "Guías para el Uso Racional de Energía por procesos en la Industria. UPB. Medellín. (1997).

[8] MUÑOZ RAMOS, ALFREDO. Metodología para la Realización de Proyectos de Uso Eficiente de la Energía en la Industria. Universidad de Chile. (2002). 